\title{
LANGUAGE OF GLOBALIZED MEDIA AS A HATE GENERATOR ON THE BALKANS
}

\begin{abstract}
The Language of hatred in its basic war inciting sense has almost disappeared from media. However, its mutants still may come out into public though intolerance or political settlements.

There is no community insensitive to some kinds of hatred. Neither developed democratic nor, even less communities in new Balkan states. Members of minority groups are specially under impact - from ethnic via religious to those specially vulnerable community groups such as handicapped, with specific diseases and juveniles and alike.

This paper is about that tolerance and hatred which still exists in media on Balkan. The writer points to the relationship of journalists to those minority groups and offers some of possible ways for improving the relationship between them.
\end{abstract}

KEY WORDS: media, tolerance, speech of hatred, discrimination, minorities.

1 mayavuyinovic@gmail.com

This paper was submitted on May 7, 2016 and accepted for publication at the meeting of the Editorial Board held on September 29, 2016. 
The transition in the last decade of the twentieth and the beginning of the 21st century, which has affected the Balkans' media sphere, has also brought a number of significant changes in this field, among which are especially notable ones that have occurred in the economy and the deontology of the media. In accordance with generally accepted neo-liberal doctrine in this region, a multiannual concept by which the media was in the ownership of the state was abandoned and a full recognition of private property was experienced. Once extremely important creators of the media reality, journalists have now become nothing more than mere executors of the will of new corporate elite that owned the largest number of the media.

Despite great expectations that all these changes would bring around prosperity not only to members of journalistic profession but also to the society as a whole, it didn't happen. Throughout turbulent years when games of great geopolitical forces took place in the Balkans, and when the disintegration of SFR Yugoslavia also happened, the media became servants of the current regime. They increased nationalistic passions and ethnic conflicts with abundant use of hate speech. Something similar is happening even today, two decades after the end of military actions in the region.

This situation actually inspired the writing of this work, which is about the hate speech in the Balkans', now globalised, media. The language of today's media is so burdened with stereotypes and prejudices that it leads directly to inciting hatred in this region, which has always been referred to as a 'barrel of gunpowder'. A special role in all this is played by the Internet that is supposedly the most democratic means of media.

Hence, the question about where the boundaries between unlimited media freedom and potential dangers that come out of them are is the right question to ask. It is about a paradox of tolerance that Karl Popper drew attention to: Should we tolerate something that should not be tolerated? (Popper, 1996:84). 


\section{FREEDOM AND HATRED}

Freedom of speech is acknowledged as a human right in the Article 19 Of The Universal Declaration of Human Rights, and is one of the founding pillars of a democratic society. It involves the freedom of information flow and the right to speak freely without a fear from punishment or revenge. It is generally considered that the freedom of speech is related to the public's right 'to know', that is to be informed. Within this context, the media play the main role because they enable public debates about public welfare by providing variety of information, ideas, beliefs, political options, and so on. They are also watchdogs of democracy that both shapes public opinion and forms a critical public. ${ }^{2}$

It should be known that it is extremely difficult to define hate speech. Under this term, media and law theorists usually mean all ways and forms of public expression of ideas and information, verbal (written or oral) as well as non-verbal (painting, drawing, illustration, signs, symbols, gestures, symbolic acts, etc.).

An American theorist Samuel Walker defines hate speech rather generally as a kind of speech that "traditionally includes every form of expression considered offensive to any racial, religious, ethnic or national group". ${ }^{3}$ Rodney Smolla defines it as "a generic term that encompasses the use of speech to attack a race, ethnicity, religion or sexual orientation or affection". ${ }^{4}$ Sandra Coliver defines it as "an expression that is abusive, insulting, intimidating, harassing and/or incites violence, hatred or discrimination". ${ }^{5}$ For Mary Matsuda "hate speech/..../ involves offensive language for racial groups, humiliating caricatures, threats of violence, literature that depicts Jews or people of any other skin colour similar to animals' and demands their extermination." Matsuda determines three fundamental characteristics, or criteria, for distinguishing the

2 For further reading Turcilo Lejla. 2014. Internet freedom and online hate speech: Media politics and the internet in Bosnia: Internews in Bosnia and Herzegovina.

3 See: Walker, S. (1994). Hate Speech: The History of an American Controversy, Lincoln: University of Nebraska Press, p.8.

4 Smolla Rodney, A. (1992). Free Speech in an Open Society, New York: Alfred A. Knopf, p. 152.

5 See: The Article 19 (ed. Sandra Coliver): Striking a Balance - Hate Speech, Freedom of Expression and Non-discrimination, University of Essex, 1992. 
worst racist hate speech messages: firstly, it has to be a message about a racial inferiority; secondly, the message has to be directly against a particular historically oppressed group; and thirdly, the message has to be persecutory, hateful and degrading. ${ }^{6}$

One of hate speech definitions is contained in the appendix of Recommendations of the Ministerial Board of European Committee No.R (97) 20 on "hate speech". This document shows that "hate speech includes all forms of expression that spread, incite, cause or justify racial hatred, xenophobia, anti-Semitism or any other form of hatred based on intolerance, including intolerance expressed in a form of aggressive nationalism and ethnocentrism, discrimination and hostility against minorities, migrants as well as people of immigrant origin".?

Unfortunately, there are many misunderstandings and misconceptions about the meaning of the term hate speech in our general public (even competent one). The hate speech is commonly identified with forms and contents of public speech that the phrase in its meaning does not involve. In this act of spreading around 'term misconceptions', politicians expectedly lead (especially the ruling ones) as they easily, but unjustifiably, turn every serious critique at their expense into a hate speech.

Also some journalists, political commentators and even individual activists of various non-governmental human rights organizations, often, although in good faith, ideologically label as a hate speech political ideas and opinions that are different from their own conceptual paradigms (left or right provenance, no difference), going further and demanding their judicial prosecution and punishment.

It is by no means certain that the media criticism of the government, government policies or actions, as well as political opinions of individuals in the authority do not appertain to hate speech, no matter how harsh, unjust, shocking, disturbing, hateful or offensive criticism was. Statements, such as, 'treacherous Government', 'commie Government', 'authoritarian regime', 'corrupted Govern-

6 Matsuda, M. J.(1993). "Public Response to Racist Speech: Considering the Victim's Story", u knjizi: Matsuda, Mari J, Lawrence, Charles R., Delgado, Richard, and Crenshaw, Kimberle Williams (eds.): Words that Wound: Critical Race Theory, Assaultive Speech and the First Amendment, Boulder, Westview Press, p. 23-36.

7 Recommendation No. R (97) 20 of the Committee of Ministers to Member States on "hate speech", od 30. oktober 1997. 
ment', 'criminal organisation', 'President snitch" and similar ones, are not examples of hate speech in the legal sense of the term, even if they were motivated by hatred. However, statements such as, 'The Romani are dirty', 'The Jews are responsible for the Holocaust', 'The Muslims are terrorists', 'The Croatians are genocidal people' and so on, undoubtedly are hate speech illustrations, even though their authors were not personally motivated by hatred.

\section{BALKAN MEDIA PAB}

During thirties of the previous century, the famous Croatian writer Miroslav Krleza in his famous work "Dialectic antibarbarus" ${ }^{8}$ wrote that "only our chases are permanent", that this is the constant and that "permanent and irrevocable spirit of chase - the law of knife is in action". Those words, as well as the pictures of his "Balkan inn" where the lights are again extinguished, are the synonyms for the state of spirit on the space ex Yugoslavia, even wider, on the space of Balkan. Politicians, here, turn off the light, and journalists accept the laws of the darkness characterized by intolerance, hatred, xenophobia, even racism. Not long ago in the area of West Balkan, that darkness which thickness was contributed by electronic and printed media run up a lot of evil.

There is no community insensitive to some kinds of hatred. Neither developed democratic communities, nor communities in transition, even less communities in each of new born Balkan states. There, where there are consolidated system institutions, where there is the system of value, where there are relations between groups more or less stable - media are, of course speaking of informative media, only one of the pillars of democratic society. In countries, where the democratic process is being established, where the democratic institutions do not exist at all or exist only on the paper, or so fragile that loud statement of a futile nationalist may move from their bearings - the media are the only controller of the rulers and only conjunction between rulers and those who allegedly elected them. In the countries of south-east Europe this is to be the case. Adding to this wars from 90. and the role of media had during that period - of course not all, but many of them most influential - actuating the conflict, using myths, legends, pieces of

8 Krleža, M. (1983). Dijalektički antibarbarus, Sarajevo: Oslobodjenje. 
history, stereotypes, speech of hatred, up to the level that someone paraphrased Klauzevic ${ }^{9}$ by defining war as continuation of the TV news by arms, it may be said that media are able or have to reverse. Media themselves do not have power - those who use them give them the power, that is - control them. So, in reverse proportion, the same power and noxiousness which, let's say TV Serbia had when distended the hatred towards others, those different whether they belonged to other religion, nationality, ethnicity, other political orientation - now it may use the same enthusiasm, energy and will, for promoting the other and different as the source of welfare, and other and different that brings new quality, new challenges which enrich.

Non of the communities from ex Yugoslavia are homogeneous, not in ethnic, nor national, nor religious, nor social, political or other sense. That is way media are to express that promiscuity of society where they exist and address to. Instead of telling us what to think, media are to offer as many as facts, and to let conclusions to well informed citizens.

The evil is dangerous for itself, but even more dangerous when it receivs the media support and political verification.

Well known Serbian political scientist Slobodan Antonić recently warned that

"trouble has never started when the crowd howl. The trouble started at the moment when the leaders agreed to that yell. The crowd may demand someone to be hanged. Trouble, however, comes at the moment when their leader says to them: "You are right! here is the loop"! Words "Fascism" and "Nazism" are verbal loops around human necks. When they are once put, it is hard to be removed. And very easily they can transform into real loops..." (Antonić, 2006).

Mil's statement is important for our discussion: "The freedom of the individual is limited so that it can not disturb the other people" (Mil,1988). This general term of freedom may be applied to freedom of expressing, that is the freedom in mass media. If a person thinks about something, this is only for himself, belongs only to him. However, the moment he expresses what he thinks about, then those utterances become public, once pronounced they can not be returned to the source they come from. More precisely, emitter sends the message and the recipient receives it. Once a message is been sent can not be returned. Through mass media, a message,

9 Clausewitz, Carl von. (1937). Vom Kriege. Berlin: K. Linenbach. 
very fast, reaches a great number of recipients. Because of the independent life of utterances in public sphere, it has to be taken care of responsibility of those who pronounce them. In social community based on individualistic view on the world the freedom can not exist without responsibility. Self defining of a man as a social being is an imperative demand, for if the man is free to express himself the way he believes, than it is necessary to be responsible for the consequences caused by the expression of his. (Mil, 1988)

Concise psycho sociological definition of hatred phenomenon follows like this: hatred is negative instance. However, emotion as a state of mind is complex phenomenon, no matter it is positive, negative or something in between. Hence, the negative emotion, such as hatred can not be totally ignored, but it should be stopped with all available means that modern civilization knows. The speech of hatred is in fact - anti communication.

\section{LANGUAGE OF HATRED MUTATIONS}

The tolerance is antipode of hatred. It does not cure the hatred, nor is the surrogacy of love, but suppresses it, which is the sufficient argument for the modern and civilized community to affirm and promote it. Tolerance should be accepted as a process of mutual understanding and acceptance of the other and different. Tolerance is the reliable instrument in promoting of fundamental human rights and freedom.

Unfortunately, here we are the witnesses of wrong interpretation of the universality of human rights. In fact, universality in Balkan way is reduced to privileges demand as pre wording of protection. Briefly, the privilege is the motive that pushes people into national corrals which eventually turns into - intolerance.

Ignorance is the vital determiner of intolerance. Ignorant people are fed with myths and mythology, half truth and stereotype, literary fictions and similar. Primitive and not educated people are the excellent target for manipulation of any kind. This characteristics has its deep historical roots and offers relatively reliable explanation of ideological - political sources of speech of hatred.

Practically, it is impossible to locate in time the historical roots of intolerance phenomenon, but relatively precisely, it can be said that great religions through centuries, probably not by the motive, 
but according to their action, were powerful generator of hatred and intolerance manifestation. Those are first of all three great religions - Judaism, Christianity and Islam. Namely, it is indisputable how ideological - political context of phenomenon of intolerance is based on ethno nationalism, which, again comes out of religious belonging. That is why the ethno nationalism is dominant political ideology which offers suspicious interpretations of historical process, social appearances and their conditionings and interchanging.

Here it is necessary to distinct between speech and language of hatred. Are they synonyms? There are many answers. In a work collective terminology, speech or language of hatred are synonyms. However, in expert and scientifically founded psycho - social, socio - cultural, anthropological - cultural and communicational communicological elaboration, the language of hatred is, first of all connected to expressing of intolerance spirit via media, while speech of hatred is connected for public activity in other channels of communication, formal and informal. This includes the whole of public sphere - politics, culture, art, science/ quasi science, education, sport. There is the private sphere which also generates spirit of intolerance, that is actuate the speech of hatred : sport fields, pubs, street and similar. No doubt, the speech of hatred leads to political violence, the most difficult breaching of human rights and, logically in final instance to crime.

Darko Plevnik, journalist and publicist from Zagreb divided the speech of hatred into "speech of hatred, script of hatred and picture of hatred" which follows the above mentioned dilemma are the speech and language of hatred synonyms? According to Plevnik, there is the greatest disturbance in the practice that existed in area of ex Yugoslavia according to which the manifestation of spirit of intolerance is the barometer of someone's patriotism: "I will lie for my country if it is necessary" a young Croatian journalist said once. In fact such an attitude release its advocates of fundamental moral category - responsibility. Plevnik spoke of the aspect of the profession having in mind destructive role of media in exciting of wars on the territory of ex Yugoslavia. Unfortunately, Balkan nodes are apparently unravel. There is no consensus about the war character waged on this territory. There is still search for pathological - anatomic diagnoses of death of Yugoslavia. Interesting remark of a Russian poet from the period of cold war that we all have our Hiroshima, but with the slow explosion, perfectly fits into 
this political ambience and mental and spiritual texture of people. Apart from that frustrations are numerous and powerful.

In years immediately after the end of the war in Yugoslavia there was the expansion of speech of hatred. This is explained by the fact that the war was so terrible, horrible and painful that severe traumas were left. In spite of this, there is today in media from this territory less direct, open language of hatred. However, it is obvious, specially in tabloids, that disgusting language of hatred mutate. The minority groups are under impact. It is almost always written about them in connection to same conflicts, even criminal activities, and then in great percentage, their behavior is generalized.

What worries is the fact that media still manipulate with the number of killed, perished and disappeared during the previous wars. This manipulation presents litmus test of political wisdom, citizen maturity and professionalism of media elite members.

It should be known that this manipulation is not our invention, and it must not be forgotten that still the reliable formula of defining of number of killed and disappeared in wars trough out the world has not be found yet, specially referring to civil wars. Human losses in American civil wars are still in rough estimations: from 300 to 500 thousand. Deviation in the number of killed in the Spanish war are more obvious. It is said in numbers from 400 to 800 thousands !? The example of these two wars tell about unreliable methodology, without politization. But here, however, that manipulation is politically motivated: from Jasenovac, so called Krizni put/ Blajburg, via total number of victims on territory of Yugoslavia from the Second World War up to the last wars.

Almost three centuries ago the Cardinal Richelieu (Armand Jean $\mathrm{du}$ Plessis de Richelieu) said that the word is deadlier than the sward. The words are, of course, followed by script and picture. The importance of the picture, that is visual is very often neglected in analyzing the definition of language typology, that is speech of hatred.

There are many reasons because of which media instead of spreading of tolerance become most important canals for intolerance and hatred spreading. People who lead media very often are not aware of power of that media and rather look up to those "above" than to those "down when creating editorial policy. Then, these people are chosen to lead media from those "above"...At the same time those "above" do not still have the wish to lead their 
communities toward tolerance, that is to more tolerant discourse. Everything is still general - if we want to go into the World of Europe, if we want to got into EU, if we want other international organizations - there are rules to be followed. One of it is the accepting of the right to be different, in ethnic, national, cultural, political and in sexual way. Many on this territory have understood that and generally accepted that. Accepted, lets say, "Appreciation frames of the ethnic minority rights". But it is only on the paper. In practice those others are still considered to be by the principle "they are all the same". Ethnic topics and actors are presented "politically". It means that ethnic differences still - several years upon ending of wars - interpret in media mostly as potential source of political differences and confrontation. Media discrimination often is the consequence of open leaning on stero types or prejudices, but often journalist practice which is considered to be routine, even professional way of presenting events.

National media, such as state television and radio have special program about ethnic minorities and very often is thought that by this the problem on appropriate treating of minority rights and problems in media is absolved. However, such programs, never the less that there is the opinion that they are welcome, express a kind of media ghetto - even from both sides: other programs think that this is enough because minorities have one "corner" for themselves. And if that program is on minority language without translation - then this is additional ghetto because who those programs address to but to minorities. So, stereotypes about them remain, and the road to main program is narrow, almost closed. Again, often are the people who work on these programs elected by "political belonging", and not according to professional qualities, which additionally gives impression that they are worse journalists, and in connection to this that they are worse communities. Programs in minority languages or plainly for minorities are often reduced to dancing in folklore garment and preparing of traditional meals, and thus create one more stereotype, and it is that minorities do not work anything else but dance "traditional dances' and prepare "traditional cookies". This is not useful for minorities.

It is good to have program for minorities (BBC has the program on Saturday morning for British originating from Asia, and recently Asia Network radio station has been started), but, if we want to know more about minorities - then those programs have to be 
translated into language of majority. And - the most important - to be professionally produced. If we really want to be open societies where everyone will feel as at home, and there is no reason for ethnic minorities not to feel like that, specially not in this part of Europe - then so called mainstream, majority program, has to be opened to minorities. Only there where you feel like at home you will not leave. If British have done so much for their minorities, whose members have stared to come in Britain only since second half of $19^{\text {th }}$ century, why then it can not be done on the territory of former Yugoslavia where many ethnic communities exist for centuries. So, instead of speaking about minorities only in political context, before elections and wars, and instead of mentioning minority nationality of criminals - television, specially public should take them into account when creating "news agenda" Finally - we are all minorities in one moment.

The media themselves are not enough professionally trained to deal with the problems of speech of hatred, ethnic intolerance and inadequate treating of ethnic and other minorities. This also refers to state, there where they exist, and to private. The first once go through painful and long process of transition into public services, while the letter often do not exist for the sake of informing of citizens but for the sake of promoting of owners who are often businessmen whose better image depend on owning at least newspapers if it is not possible to have television. Owning of media is often the way to laundry the business, both literally and factually. So, there is often the lack of professionalism to both.

CONCLUSION In order to make a positive role in overcoming problems brought by the speech, that is language of hatred, it is necessary, among other things, for politicians to understand that media do not exist to serve them but the citizens. On the other hand, people in media have to be more self confident and have self respect and turn to self regulation and real role. of course, there will always be media, as in most democratic communities, which will be advocates of hatred, and this is one of the prices of free thought, free press and the pluralism of opinions. Media that here spread hatred do not perform this completely aware and as a thing of their choice. Very often this is performed out of persuasion that the bad news will sell better and faster the press than the good news.

Also, to stop the speech of hatred in media it is necessary that each media house has its "house order" - practically the guide for 
journalists which will in unique and direct way guide journalist how to write about this topics. This has every journalist house in so called developed world. If you get the job for BBC, you have to read the guide carefully and you will be bound by the contract to accept it. So, before you start work for the BBC you have to know exactly how to write on ethnic communities, which words are allowed, terminology, how to write about elder, children, people with certain physical or mental disturbance, how to write about fat..... No, this is not about political correction. This is about, as recently the representative of $B B C$ said, that everyone who listens / watches $\mathrm{BBC}$ feel as a part of society, equally connected and respected as all others, as minority, as majority.

Followers of self - regulative, consider the journalists to be able to take care of their profession, that they are responsible enough and that is why they declare that certain bodies, commissions, no matter what their names are, independent from political centers of power, and respected by the citizens - may take over the role of judges when the journalist make mistakes in connection to their profession, thus to their "consumer" and in that sense they propose sanctions, conducted by media itself. Law may help only partly. For sometimes insults are of the character that apology, correction or suspension of the journalist is not enough. As it would not be enough in some other profession, if you make a crime over somebody.

Antonić, S. (2006). Verbal war on political scene: Who turns off the light over Serbia, Novi Sad: Dnevnik.

Clausewitz, Carl von. (1937). Vom Kriege. Berlin: K. Linenbach.

Krleža, M. (1983). Dijalektički antibarbarus, Sarajevo: Oslobodjenje.

Matsuda, M.J.(1993). "Public Response to Racist Speech:Considering the Victim's Story", u knjizi: Matsuda, Mari J, Lawrence, Charles R., Delgado, Richard, and Crenshaw, Kimberle Williams (eds.): Words that Wound:Critical Race Theory, Assaultive Speech and the First Amendment, Boulder, Westview Press.

Mil, J.S. (1988). About freedom, Belgrade: Filip Visnjic.

Popper K. (1966). The Open Society and Its Enemies, Volume I, The Spell of Plato (5. revidirano izdanje), London: Routledge \& Kegan Paul

Smolla Rodney, A. (1992). Free Speech in an Open Society, New York: Alfred A. Knopf. 
Turcilo, L. (2014). Internet freedom and online hate speech: Media politics and the internet in Bosnia. Sarajevo: Internews in Bosnia and Herzegovina.

Walker, S. (1994). Hate Speech: The History of an American Controversy, Lincoln: University of Nebraska Press. 
МАЈА Р. КОСТАДИНОВИК

УНИВЕРЗИТЕТ У НИШУ

ФИЛОЗОФСКИ ФАКУЛТЕТ

РЕЗИМЕ

ЈЕЗИК ГЛОБАЛИЗОВАНИХ МЕДИЈА КАО УЗРОЧНИК МРЖЮЕ НА БАЛКАНУ

Језик мржње у свом изворном ратно хушкачком смислу готово да је нестао из медија. Међутим, његови мутанти и данас знају пробити у јавност кроз предрасуде, нетрпељивости или политичке обрачуне.

Ни једно друштво није сасвим имуно на неке врсте мржње. Ни развијена демократска, а још мање друштва у новонасталим балканским држава. На удару се посебно налазе припадници мањинских група - од етничких, преко верских, до оних посебно рањивих друштвених група какве су инвалиди, оболели од разних специфичних болести, малолетници и сл.

Овај рад посвећен је управо питањима толеранције и мржње која је још увек присутна у медијима на просторима Балкана. Аутор указује на то како се журналисти односе према припадницима мањинских група и нуди неке од могућих путева за поправљање односа према њима.

Кључне речи: медији, толеранција, говор мржње, дискриминација, мањине. 